\title{
„Specjaliści” od UE. O myśleniu potocznym jako granicy poznania wspólnoty europejskiej a sprawa polska (esej)
}

\section{Wprowadzenie. O pornografii demokracji}

Unia Europejska zbudowana jest w duchu prawa rzymskiego - normatywnie, biurokratycznie, jakby paragrafy, regulacje, traktaty miały być protezami myślenia krytycznego implicite progresywnego, dialogicznego, upodmiotawiającego integrację. Dopiero od niedawna zaczęto rozmawiać o Europie wartości etycznych (co zapewne ma swe źródło m.in. w kryzysie uchodźczym, w wykluczeniu różnie pojmowanej inności, w zagrożeniach ekologicznych). Ani po polsku, ani po angielsku i francusku nie czytałem natomiast analiz dotyczących nie tyle krytycznej „racjonalności” Europejczyków (w uproszczeniu traktowanej jako dziedzictwo Oświecenia), co „racjonalności" potocznej, a to właśnie ta forma myślenia dominuje w Europie codziennej, małych i wielkich miast, wsi, centrów kulturowo-politycznych i peryferii. Zasadność tej hipotezy opieram na prowadzonych od ponad dziesięciu lat badaniach odnoszących się do kultury popularnej oraz do niezliczonych wypowiedzi polityków i ich wyborców, które są zapośredniczone w mediach tradycyjnych i w Internecie'.

Piętą achillesową Unii Europejskiej jest populizm polityków oparty na emocjach oraz ignorancja $\mathrm{i}$ indyferencja obywateli UE pełniące funkcje masek kompetencyjnych, które są modelowane przez myślenie potoczne. To dlatego Wspólnotę udaje się polaryzować tak przeciętnym, choć niebezpiecznym politykom, jak Erdogan czy Putin (bo np. silna Rosja jest silna słabością swych oponentów), to dlatego można - będąc członkiem Wspólnoty - wciąż podważać zasadność jej istnienia. Viktor Orban, Jarosław Kaczyński czy Marine Le Pen w tym kontekście są użytecznymi „manekinami” o ambicjach demiurgicznych ${ }^{2}$. Oddajmy głos ojcu i narratorowi z opowiadania Brunona Schulza, zapominając o kontekście historyczno-literackim, lecz myśląc w perspektywie cytatu o tym, co się dzieje obecnie w wielu krajach Unii Europejskiej:

— Zbyt długo żyliśmy pod terrorem niedościgłej doskonałości Demiurga — mówił mój ojciec — zbyt długo doskonałość tego tworu paraliżowała naszą własną twórczość. Nie chcemy z nim konkurować. Nie mamy ambicji mu do-

${ }^{1}$ Wielość i różnorodność materiałów jest na tyle ogromna i złożona, że każdy przykład może się wydawać zbyt arbitralnie wybrany, dlatego szkicuję w tym miejscu hipotezę, której zasadność w kilku miejscach pokażę.

${ }^{2}$ Metafora manekina zaczerpnięta została z opowiadania Brunona Schulza. Podkreślam to, aby Czytelnik nie potraktował mojego wywodu jako wypowiedzi zredukowanej do nachalnych ocen. Wprowadziłem tę metaforę, aby podkreślić niesamodzielność polityczną oraz wynikający z niej koszmar destrukcji tego, co leży u podstaw wspólnoty. 
równać. Chcemy być twórcami we własnej, niższej sferze, pragniemy dla siebie twórczości, pragniemy rozkoszy twórczej, pragniemy — jednym słowem — demiurgii. - Nie wiem, w czyim imieniu proklamował mój ojciec te postulaty, jaka zbiorowość, jaka korporacja, sekta czy zakon, nadawały swą solidarnością patos jego słowom. Co do nas, to byliśmy dalecy od wszelkich zakusów demiurgicznych.

Lecz ojciec mój rozwinął tymczasem program tej wtórej demiurgii, obraz tej drugiej generacji stworzeń, która stanąć miała w otwartej opozycji do panującej epoki. - Nie zależy nam - mówił on — na tworach o długim oddechu, na istotach na daleką metę. Nasze kreatury nie będą bohaterami romansów w wielu tomach. Ich role będą krótkie, lapidarne, ich charaktery — bez dalszych planów. Często dla jednego gestu, dla jednego słowa podejmujemy się trudu powołania ich do życia na tę jedną chwilę. Przyznajemy otwarcie: nie będziemy kładli nacisku na trwałość ani solidność wykonania, twory nasze będą jak gdyby prowizoryczne, na jeden raz zrobione. Jeśli będą to ludzie, to damy im na przykład tylko jedną stronę twarzy, jedną rękę, jedną nogę, tę mianowicie, która im będzie w ich roli potrzebna. Byłoby pedanterią troszczyć się o ich drugą, nie wchodzącą $\mathrm{W}$ grę nogę. $Z$ tyłu mogą być po prostu zaszyte płótnem lub pobielone. Naszą ambicję pokładać będziemy w tej dumnej dewizie: dla każdego gestu inny aktor. Do obsługi każdego słowa, każdego czynu powołamy do życia osobnego człowieka. Taki jest nasz smak, to będzie świat według naszego gustu. Demiurgos kochał się w wytrawnych, doskonałych i skomplikowanych materiach - my dajemy pierwszeństwo tandecie. Po prostu porywa nas, zachwyca taniość, lichość, tandetność materiału. Czy rozumiecie — pytał mój ojciec — głęboki sens tej słabości, tej pasji do pstrej bibułki, do papier-mâché, do lakowej farby, do kłaków i trociny? To jest — mówił z bolesnym uśmiechem — nasza miłość do materii jako takiej, do jej puszystości i porowatości, do jej jedynej, mistycznej konsystencji. Demiurgos, ten wielki mistrz i artysta, czyni ją niewidzialną, każe jej zniknąć pod grą życia. My, przeciwnie, kochamy jej zgrzyt, jej oporność, jej pałubiastą niezgrabność. Lubimy pod każdym gestem, pod każdym ruchem widzieć jej ociężały wysiłek, jej bezwład, jej słodką niedźwiedziowatość.

Dziewczęta siedziały nieruchomo ze szklanymi oczyma. Twarze ich były wyciągnięte i zgłupiałe zasłuchaniem, policzki podmalowane wypiekami, trudno było w tej chwili ocenić, czy należą do pierwszej, czy do drugiej generacji stworzenia.

- Słowem — konkludował mój ojciec — chcemy stworzyć po raz wtóry człowieka, na obraz i podobieństwo manekina (Schulz, Traktat...).

Wspólnota zdominowana przez ludzi, których wiedza i rozumienie złożoności świata nie przekraczają granic myślenia potocznego, to wspólnota niesamodzielna, zniewolona, choć uzurpująca sobie prawo do władzy totalnej. Populiści w wielu krajach Europy, w tym w Polsce, chcą stworzyć Europę ,po raz wtóry [...] na obraz i podobieństwo manekina", na ich własny obraz, ale tak być nie musi, jeśli zdamy sobie sprawę z podstaw biologicznych myślenia potocznego. Doświadczamy jednak w tym kontekście już teraz tego, co nazywam pornografią demokracji, bo myślenie potoczne i wiedza potoczna nie są oparte na wiedzy merytorycznej, lecz na działaniach doraźnych, krótkowzrocznych, ekskluzywnych, determinowanych emocjami, redukujących obywateli do narzędzi służących podtrzymywaniu status quo rządzących. Daleko jesteśmy od Oświecenia jako postulowanej inspiracji dla dyskursów krytycznych z pragnieniem Adorno i Horkhe- 
imera o tym, by bronić go przed nim samym (Bielik-Robson, 2012, s. 27). Można nawet ogłosić, że UE bankrutuje moralnie i poznawczo. Pornografia demokracji w przypadku Polski oznacza, że władza wykorzystując instytucje demokratyczne, dążąc do autorytaryzmu (być może nawet soft dyktatury, wszak można ją wprowadzać rozpędzając konsumeryzm) - blokuje obywateli kontestujących wszelkie jej nadużycia (między innymi: zwolnienia z pracy ${ }^{3}$, procesy sądowe, areszty, ostracyzm społeczny, zawieszanie niesprzyjających rządowi sędziów w wypełnieniu obowiązków, korupcja polityczna (nepotyzm jako nagroda za lojalność, „symonia” etatami)) pod pozorem zachowywania norm i praw gwarantowanych przez konstytucję.

Celem artykułu jest wykazanie, że przyszłość UE jako wspólnoty wartości zależy od zrozumienia granic poznania wyznaczanych (projektowanych, ale też tłumionych) przez myślenie potoczne. Taki poziom ogólności przyjętej hipotezy świadczy o tym, że zamierzam pokazać wybrane mechanizmy, lecz nie roszczę sobie pretensji do tego, by wyczerpać temat.

Badania dotyczące myślenia potocznego rozwijane są na gruncie antropologicznym, literaturoznawczym, kulturoznawczym, filozoficznym i religioznawczym (Geertz, 2005, s. 84) ${ }^{4}$. Czas zatem w tym kontekście na refleksję z obszaru political studies.

\section{Myśl potoczna to myśl polityczna}

Każdy z nas doświadczył granic stosowalności wiedzy specjalistycznej. W czasie epidemii bezradna okazuje się wiedza medyczna, epidemiologiczna i biologiczna, gdy trzeba ją konfrontować z nacechowanym emocjami dyskursem podejrzeń i uprzedzeń, dyskursem symulowanym przez celebrytów i polityków. Dyskurs publiczny o walucie Euro w Polsce jest na poziomie wiedzy ekonomicznej, którą posiada dziecko czekające na kieszonkowe od rodziców, myśląc zapewne, że portfel rodziców wytwarza to dobro (w perspektywie makroekonomicznej to porównanie jest nazbyt oczywiste). Rozbisurmaniony pakiet wsparcia socjalnego w Polsce zachłyśnięty jest konsumenckim „teraz” i podłączony do respiratora działającego na oparach fałszywych przesłanek o tym, że jutro nie nadejdzie nigdy. Google leczy nasze ciała i umysły. Populizm udaje historię, a rosnąca inflacja racjonalną gospodarkę. Wykluczenie społeczne uzurpuje sobie prawo do bycia zamiast dialogu i tolerancji. Doraźny interes polityczny wma-

${ }^{3}$ Mam na myśli nie tylko polską perspektywę, lecz również węgierską. W 2015 roku na konferencji w Londynie poznałem znakomitego uczonego, historyka idei, który został zwolniony z pracy za głoszenie poglądów, które już wtedy nie podobały się akolitom Orbana. Dryfował po Europie szukając pracy.

${ }^{4}$ Clifford Geertz pisze tak: „Zainteresowanie Wittgensteina, Austina, Ryle'a potocznym językiem, rozwijana przez Husserla, Schutza, Merleau-Ponty'ego tzw. fenomenologia życia codziennego, gloryfikowanie przez europejską filozofię egzystencjalną osobistych, czysto życiowych decyzji, ujmowanie całej gamy różnorodnych sposobów rozwiązywania problemów jako paradygmatu rozumowania w amerykańskim pragmatyzmie - wszystko to odzwierciedla dążność do poszukiwania w strukturach przyziemnych i trywialnych myśli klucza do głębszych tajemnic egzystencji” (Geertz, 2005, s. 84). Widzimy zatem szeroki kontekst badań odnoszących się do myślenia potocznego. Warto jeszcze uwzględnić między innymi następujące prace: T. Hołówka (1986), J. Hartley (1996), R. Sulima (2000), Z. Kloch (2006). 
wiany jest jako działanie nadrzędne wobec norm ustalonych w konstytucji, a wartości chrześcijańskie są uniwersalne wyłącznie $\mathrm{w}$ granicach państwa budującego mury i zasieki na granicy. Prawdziwy patriota na swoim używanym volkswagenie ma naklejkę z powstańczym symbolem Polski Walczącej, a jednocześnie nie liczy się z opiniami prawdziwych uczestniczek Powstania Warszawskiego. Kradnie się symbole narodowe (przykład symbolu „Polska Walcząca”), etos (manipulacje przy biografii Solidarności i KOR-u). Neonacjonalizmy w Europie pokazują, jak zawiódł system edukacyjny oraz jak zawiodła Europa krytyczna (Karner, 2020), w jej miejsce mamy Europę potoczną, „genitalną" (do tej metafory powrócę). Jakże gorzko w tym kontekście brzmią słowa z cytowanego już opowiadania Brunona Schulza: „Ich role będą krótkie, lapidarne, ich charaktery — bez dalszych planów. Często dla jednego gestu, dla jednego słowa podejmujemy się trudu powołania ich do życia na tę jedną chwilę. Przyznajemy otwarcie: nie będziemy kładli nacisku na trwałość ani solidność wykonania, twory nasze będą jak gdyby prowizoryczne, na jeden raz zrobione".

Unia Europejska jest wspólnotą deklaratywną na tym poziomie: wiemy, jak mówić o tym, na czym nam zależy, ale nie umiemy tego egzekwować, dlatego wspólnota rozpada się na fraktale banału. Unia Europejska w polskim dyskursie politycznym traktowana jest instrumentalnie przez rządzących, którzy raz każą się fotografować na tle flagi UE, innym razem już nie. Ta gra na symbolach świadczy bez wątpienia o przebóstwieniu emocji, tymczasowości i ignorancji, ale mieści się w granicach myślenia potocznego. Ta gra na symbolach świadczy również o tym, że UE w dobie populizmów węgierskiego (Orban), francuskiego (Le Pen), polskiego (Kaczyński) jest oswojonym innym. Oswojonym, gdy czerpie się korzyści finansowe, innym, gdy trzeba wskazać przyczyny własnej nieudolności politycznej, zasłaniając się wrogą polityką „Brukseli”, „Paryża”, „Berlina”.

Odnoszę wrażenie, że twórcy UE, o czym wielokrotnie pisano w różnych kontekstach na łamach „Rocznika Integracji Europejskiej” i innych czasopism, żywili przekonanie, że wszyscy lub zdecydowana większość Europejczyków myśli tak, jak oni: deontologicznie oraz progresywnie. Unia Europejska wciąż będąc palimpsestem idei Oświecenia europejskiego miała się doskonalić na drodze rozumu, miało przybywać wiedzy specjalistycznej służącej polepszaniu jakości życia, jak i miało wzrastać jej zastosowanie, dóbr miało przybywać, a narody miały się stawać wspólnotami. Jesteśmy jednak w momencie, gdy Europa się chwieje wewnętrznie, duży w tym udział Polski czy Węgier, to, że UE jest śmiertelna - pokazała nam złożona gospodarczo, politycznie i kulturowo sytuacja wynikająca z brexitu. Rosja doskonale gra z Unią, znając resentymenty swych braci i sióstr mniejszych, USA wikła się w psychoanalizę traktując siebie jako „fantazmatyczne ja” jednoczącej się Europy. Chiny w tym kontekście chyba nawet nie zauważają wspólnoty, lecz dostrzegają zaledwie rozproszone rynki, nad którymi łatwo można zapanować.

Niby dlaczego zjednoczenie Europy miałoby być bezkolizyjne, skoro przeszłość Europy to przeszłość wojen, stosów, wiedzy zinstrumentalizowanej, krwi i popiołów, i literatury, która przecież nie zabliźni ran i nie wskrzesi ofiar wojen, pogromów, uprzedzeń. UE, mówiąc językiem Nietzschego, jest wspólnotą reaktywną na poziomie wartości, aktywną wspólnotą staje się na poziomie administracji i prawa (choć tutaj już odchodzimy od idei nietzscheańskiej). Wspólnota reaktywna to wspólnota 
reagująca na strach przed rozpadem, to wspólnota reagująca na działania dużo bardziej skonsolidowanych wielkich graczy, jak Rosja, to wspólnota rozwiniętej biurokracji będącej fantomem tożsamości różnych ludzi, języków, tradycji, kultur i celów. Wspólnota reaktywna to wspólnota bezradna na zagrożenia ekologiczne, to wspólnota spolaryzowana przez nadambitne peryferia (Węgry i Polska destabilizują) i narcystycznie usposobione centra (Niemcy i Francja pouczają). Wspólnota reaktywna to wspólnota wielkich projektów, które muszą się ,zmieścić” w Excelu i których zasadność oraz „racjonalność” należy potwierdzić przeprowadzając analizy SWOT. Myślenie potoczne, które, moim zdaniem, jest dominującą formą „,racjonalności” nadającej sensy i znaczenia w dyskursach politycznych oraz ekonomicznych (widocznych w skali makrospołecznej i mikrospołecznej w codzienności), pozwala umierać Unii częściej, niż Nietzsche chciałby śmierci Boga. Nasz paradoks jako Europejczyków polega właśnie na tym, że wspólnota europejska pełna jest celów. Każdy, kto składał jakiś grant unijny, zna słowa typu: aim, objective, purpose. Wspólnota jest pełna celów, lecz nie ma celu, który uczyniłby ją szczęśliwą, jednoczącą się z powodu uznawanych wartości (nie mówię o deklaracjach, lecz o praktycznym działaniu). Nie ma nikogo, kto łączyłby Europejczyków, był ich wspólnym dobrem.... Goethe? Wielki pisarz, ale nie lubił pudli (Bringsvaerd, 2020, s. 211), poza tym, kto dziś dobrowolnie sięga po jego dzieła. Nie ma autorytetów europejskich, bo wspólnych. Mówienie o Europie wartości wydaje się naiwne i pretensjonalne. Kiedy Europa była wspólnotą wartości? W czasie wypraw krzyżowych, wojny stuletniej, palenia na stosie, rewolucji przemysłowej, I wojny światowej, a może po II wojnie światowej? Kiedy? Gdy myślimy Europa, to natychmiast uruchamia się w nas przekonanie, że to świat wielkich miast, centrów politycznych, biznesowych i przez grzeczność dodam - akademickich, a, i rolników. A przecież Europa to również małe miejscowości, w których upamiętnia się wielowiekową niesprawiedliwość, jak np. spalenie żywcem dziesięciu niewinnych kobiet w 1761 roku 30 września. Do dziś lokalni mieszkańcy upamiętniają tamtą zbrodnię. Badałem ten teren i na podstawie rozmów z mieszkańcami okolicznych wiosek mogę stwierdzić, że pamięć o dziesięciu skazanych na śmierć kobietach opiera się na niezmienionym od setek lat elementarnym poczuciu sprawiedliwości, które przecież oparte jest na myśleniu potocznym. Oto sąd w Kiszkowie skazał niewinne kobiety na śmierć, wszystko więc przebiegało zgodnie z ówczesnym prawem. Sądy w Gnieźnie i w Pobiedziskach odmówiły procedowania w tej sprawie. A więc mamy w tej historii jedynego rzeczywistego ,adwokata” zielarek z Gorzuchowa, czyli właśnie pamięć przekazywaną z pokolenia na pokolenie w języku potocznym. Historia ta uczy, że system prawny obowiązujący w kraju jest zawodny, że niewinny człowiek jest bezbronny wobec kogoś silniejszego od siebie, że Kościół przybywa z pomocą za późno, ale też - że zwykli ludzie pamiętają. Musimy, myśląc o Europie jako o wspólnocie wartości, pamiętać także o zielarkach z Gorzuchowa. Dlaczego? Bo pamięć o nich jest aksjologicznym filtrem, który służy destylacji norm narzucanych jednostkom przez dyskurs władzy. Europa jako wspólnota wartości zapewne zbankrutuje, zanim cokolwiek w polu semantycznym tego pojęcia zacznie się wyłaniać, bo wyklucza z historii nie tylko zielarki, ale także to wszystko, co pokazuje jej autentyczną złożoność. I to właśnie przez tę złożoność można wciąż budzić demony nieufności, uprzedzeń, wykluczenia żerujące na zgliszczach przeszłości. Przecież „wiemy”, jak było i jak jest: 
Niemcy to Niemcy, a Bruksela to Bruksela. Za tym tautologiami kryje się jednak rzeczywiste, łatwe w użyciu, wykluczenie oparte na stygmatyzacji. Łatwe w użyciu dla każdego, kto posługuje się myśleniem potocznym, unikającym weryfikacji wiedzy, którą się posiada, unikającym krytycznego namysłu, unikającym poznawania faktów, skoro $\mathrm{w}$ ich miejsce można podstawić zawsze łatwopalne emocje thumu. UE zrezygnowała z lub nie rozpoczęła budowania społeczeństwa odpowiedzialnego i mądrego, szczerze powiedziawszy, nie wiem nawet, jak miałaby to uczynić. Postulowanie wartości etycznych opiera się na myśleniu idealistycznym, nadrzędność narzędzi ekonomicznych wobec aksjologii to sfera realizmu. Oczywiście, w Europie deklaruje się tolerancję, krytykuje się homofobię czy antysemityzm, ale właściwie mechanizmy, które się w tym kontekście wykorzystuje, są mechanizmami reaktywnymi.

Powyższe zdania są bez sensu, o ile cechy podmiotu sprawczego przypisane zostały abstrakcyjnej wspólnocie. Należy więc doprecyzować desygnat. Nie mam na myśli, pisząc o podmiocie sprawczym, wyłącznie urzędników unijnych ani innych osób zawodowo aktywnych na niwie integracji i rozwoju Unii Europejskiej, lecz nas jako Europejczyków, którzy wspólnotę odmieniamy przez deklinacje codzienności. To nasze życie zachłyśnięte jest pokrytymi już rdzą, ale wciąż trochę modnymi tezami Fukuyamy. Nawet sobie nie zdajemy sprawy, jak konsumeryzm (zjawisko nabywania i sprzedawania dóbr materialnych, którym nadajemy znaczenie porównywalne z religijnym) (por. Jameson, Postmodernism...) wpłynął na nasze bycie w czasie, choć to niejedyna przyczyna opisywanego stanu rzeczy.

Coraz trudniej zamieszkuje się nam współczesny świat. Zmiany klimatyczne (choć w tym kontekście to pojęcie brzmi jak niezgrabny eufemizm). Kryzys uchodźczy. Niestabilność rynków finansowych. „Parowanie” hegemona: USA jakby się wycofuje, a UE nikogo innego w tej roli nie chce widzieć. Populizm. Neonacjonaliści stają się pleśnią każdej demokracji (Karner, 2020). Tarcia z sąsiadami UE: Turcja zgłaszająca pretensje do wysp greckich, Białoruś sprawdzająca nietykalność Litwy. Sojusze wbrew wartościom: układ niemiecko-rosyjski (NORD STREAM) ślepy na to, co Rosja niszczy na Ukrainie, wszak wartości ekonomiczne i polityczne wydają się nadrzędne wobec etycznych (wiadomo, „dogmat” o nadrzędności realizmu nad idealizmem w polityce) (Korab-Karpowicz, 2010) . Pandemia. W poszczególnych krajach narastają podziały spowodowane różnicami religijnymi i etnicznymi (Francja), politycznymi i społecznymi (Polska), etnicznymi i ekonomicznymi (Austria). Współczesny świat coraz trudniej zamieszkiwać, bo przecież zaczyna nam brakować nie tyle woli życia, co wody, dachu nad głową i pożywienia (Leggewie, Welzer, 2012, s. 15-68). Wielu z nas boi się o przyszłość życia na Ziemi, o przyszłość dzieci, o zwierzęta. I nie wiemy, co z tym strachem zrobić. Piszę ,strachem”, bo przecież możemy konkretnie wskazać, czego i kogo się boimy. Europa reaktywna to Europa strachu, który jest śladem - oczywiście na dużym poziomie abstrakcyjnego myślenia - po tym, czego można się było spodziewać, gdy Europa zaczęła siebie wymyślać na nowo w epoce szeroko rozumianego, różnie w wielu krajach się przejawiającego Oświecenia. I nie trzeba znów na baczność stawiać XX wieku z jego wojnami, żeby zrozumieć, że to, co logiczne - zawsze jest bezradne wobec tego, co potoczne, a szczególnie wobec tego, co

${ }_{5}^{5}$ Por. uwagi o tzw. dialogu melijskim na podstawie Wojny peloponeskiej Tukidydesa w książce W. J. Korab-Karpowicza, Historia filozofii politycznej. Od Tukidydesa do Locke'a, Kęty 2010. 
genitalne, to kwestia dysproporcji oraz dostępności przekazywanej wiedzy. Wspólnota staje się reaktywna, bo jest popędowa. Europę zaczyna determinować popęd śmierci przejawiający się w destrukcji podstaw demokracji, środowiska naturalnego i partykularyzmach będących bastardami XIX-wiecznych podziałów, w polityce kolonialnej i w chciwości. W Europie przewartościowuje się strach, którym łatwo zarządzać politykom i służbom różnych wywiadów. I innej Europy nie będzie. Ważne, żeby się zastanowić nad tym, co zrobić, żeby nie tylko taka była. Nie tylko taka, a więc jaka?

W ogromnym uproszczeniu przywołam tutaj z Państwa Platona ważną triadę: logos, ethos i pathos. Proszę mi pozwolić, że tę triadę przetłumaczę w następujący sposób: wiedza, norma i genitalia. Unia Europejska na poziomie deklaratywnym to wspólnota norm, lecz na poziomie codziennych praktyk to wspólnota genitalna: emocjonalna, rozchwiana między konfrontującymi się popędami erotycznymi i tanatycznymi. Polacy chcą ufać Niemcom (eros), więc chętnie biorą udział we wspólnych międzynarodowych projektach naukowych czy biznesowych, ale jednocześnie są wobec nich nieufni (tanatos), więc głosują na partie wciąż odwołujące się do instrumentalnie przywoływanej przeszłości (Tenenbom, 2016) .

W 2018 roku wziąłem udział w seminarium organizowanym przez Fundację Adenauera ${ }^{7}$. To ciekawe, że jeden z uczonych deklarujących się jako człowiek dialogu i zwolennik wspólnoty europejskiej nie był w stanie mówić o współczesnych relacjach polsko-niemieckich inaczej, jak tylko w perspektywie czasu przeszłego, i dodam: silnie zideologizowanej (podaję przykład akademicki, żeby pokazać, iż od dychotomii erosa i tanatosa (piszę z małej litery, żeby podkreślić, iż są to metafory poznawcze odnoszące się do dyskursów politycznych i quasi-politycznych) nie są wolne uczelnie). Wspólnota reaktywna to wspólnota, w której tanatos jest nadrzędny wobec erosa, gdzie niepewność, strach, brak zaufania, resentymenty i emocje konstytuują wykluczające narracje, sankcjonując populizm (widzimy to na przykładzie gry politycznej „w polexit” - PiS deklaruje, że nie chce wyjścia z UE, chowając flagi wspólnoty do szuflady i niszcząc praworządność, opozycja przekonuje, że PiS chce wyjścia Polski z UE, jakby się nie wiedziało o tym, że w pewnym momencie kraje członkowskie mogą już nie chcieć Polski w swoich szeregach).

\begin{tabular}{|c|c|c|}
\hline $\log 0 s$ & ethos & pathos \\
\hline wiedza & norma & genitalia \\
\hline kreacja & balans & destrukcja \\
\hline
\end{tabular}

Zakładam, że logos i kreowana w jego horyzoncie wiedza są erotyczne, afirmatywne i aktywne, gdyż wciąż zakładamy, że coś można stworzyć wspólnie przy wykorzystaniu wiedzy, którą dysponujemy, a gdy dodamy do tego myślenie o przyszłości, to

${ }^{6}$ Książka Tuvii Tenenboma jest ciekawym przykładem na to, jak myślenie potoczne „mieści” w sobie całkowicie różnorodne, arbitralne sposoby myślenia o przeszłości.

7 XX. QUIRITENTREFFEN DEUTSCH-POLNISCHER QUIRITENKREIS der Konrad-Adenauer-Stiftung Wie hast du's mit der Europäischen Union? Polnische und deutsche Antworten auf die europäische Gretchenfrage, 19.10.-21.10.2018. 
uruchamiamy działania, które indywidualnie wydają się bezinteresowne (bo nieopłacalne w perspektywie krótkoterminowej), lecz konieczne, aby życie na Ziemi w nieodległej już przyszłości nie stało się realizacją któregoś z katastroficznych filmów. Populizm na poziomie polityki w skali makrospołecznej jest tanatyczny, oznacza to, że jest reaktywny co do istoty, choć symuluje działania, dobrą zmianę, projektując wciąż nowe idee i postawy, to prawda - wystarczy mieć na uwadze metafory umotywowane myśleniem potocznym stosowane przez obóz rządzący w Polsce, czyli nieustanne „wstawanie z kolan” (jak gorzko w tym kontekście brzmią słowa z cytowanego powyżej opowiadania Schulza: „Zbyt długo żyliśmy pod terrorem niedościgłej doskonałości Demiurga”) czy też „Nowy Ład” (i dalej cytat z tego samego opowiadania Schulza: „Nie chcemy z nim konkurować. Nie mamy ambicji mu dorównać. Chcemy być twórcami we własnej, niższej sferze, pragniemy dla siebie twórczości, pragniemy rozkoszy twórczej, pragniemy — jednym słowem — demiurgii."), jednak bazuje się w tych przypadkach wciąż na wytresowanych, trzymanych w klatkach pod ziemią demonach. Gdy w tym kontekście uwzględnimy mechanizmy oddziaływania kultury popularnej na wspólnoty tworzące Europę, to zrozumiemy, że niemal identyczne mechanizmy kulturowe obowiązują w przestrzeni debaty publicznej: substytucja emocji na miejsce faktów, unifikacja dyskursu, obniżanie poziomu intelektualnego debaty publicznej, imagologia na miejsce ideologii. Pornografia demokracji przejawia się w tym kontekście również w reaktywności opozycji, która rozlicza, komentuje oraz reaguje na działania władzy, lecz sama nie wyznacza żadnego afirmatywnego projektu, który można by realizować. Reaktywna opozycja to fundamentalna słabość każdej demokracji, reakcja powinna być jedną ze strategii, a nie główną i nadrzędną, ale i tu wracamy do sytuacji zasadniczej: opozycję w tym kraju, podobnie jest na Węgrzech, konstytuują osoby, dla których również myślenie potoczne i doraźny interes polityczny wyznaczają horyzont aktywności politycznej. Podam przykład z ludowej „,paidei”: w czasach, gdy zdobycie roweru dla dziecka graniczyło z cudem, uczono jazdy bez kasku oraz bez zestawu ochraniaczy. Dzieci jeździły na rowerach, upadały, wiele było zdartych kolan i rozbitych głów. Nierzadko dramat. Dzieci jednak uczyły się myślenia przyczynowo-skutkowego: zrobię błąd - cierpię. Podejmując jednak ryzyko i wiedząc, że można coś stracić, zyskiwały dużo więcej, niż zakładały: samodzielna jazda, podróże, wspólnota, przekonanie, że ryzyko się opłaca. Opozycja to dzieci w kasku, $\mathrm{z}$ zestawem ochraniaczy, pokonujące metry gumowych ścieżek rowerowych. Wciąż się jedzie na rowerze, wciąż jest podróż, wciąż wspólnota, wciąż świadomość ryzyka, ale temu wszystkiemu towarzyszy jedna zasadnicza różnica: poruszanie się po bardzo ograniczonym terenie, po wyznaczonej przez kogoś trasie. Opozycja reaktywna to opozycja, która boi się zaryzykować ze strachu przed konsekwencjami, to dlatego na przykład głosuje chętnie w sejmie za podwyżkami dla parlamentarzystów i nie łamie regulaminów sejmowych, bo za to są kary finansowe. I niechętnie sięga po wiedzę merytoryczną, gdyż jest przekonana, opierając się na myśleniu potocznym, że przy jej wykorzystaniu nie przekona do swoich racji zwyczajnego obywatela.

Unia Europejska w postaci, którą Polska zastała w 2004 roku, była wspólnotą tożsamą na poziomie norm (prawnych), wspólnotą wspierającą liczne programy edukacyjne w celu budowania społeczeństwa wiedzy (program międzyuczelnianej wymiany Erasmus jest tego najlepszym przykładem i nie chodzi tutaj o szczegółowe daty doty- 
czące tego, od kiedy studenci polscy mogli studiować w ramach tego programu, tylko o sam projekt). Normy prawne i administracyjne służyły wypracowaniu najlepszego balansu między erosem i tanatosem, między logosem (symbiozą wiedzy merytorycznej, krytycznej i telosem) i genitaliami, między kreacją i destrukcją, choć nie była wolna od wewnętrznych sporów. W 2021 roku w wielu krajach Unii Europejskiej na różnych poziomach uprawia się destrukcyjne praktyki, które osłabiają jedność (Węgry, Polska, Włochy, Francja, jeśli skrajna prawica przejmie władzę) wspólnoty. Populizmy, nowe nacjonalizmy pokazują coraz wyraźniej, jak realna staje się destrukcyjna siła oparta na nieprzezwyciężonych wewnętrznych problemach poszczególnych krajów, a właściwie ich obywateli w Unii. Rozpad świata i implodujące w nas na skutek mediów masowych i internetowych obrazy stają się źródłem wtórnego trybalizmu: my-naród-prawdziwi patrioci itp. przeciw tym, którzy chcą nam odebrać wolność, choć przyznam na marginesie, że bardziej prawdopodobne jest to, że będziemy sobie odbierać wodę. Porządek prawny i ekonomiczny nałożone na to, co nie zostało uporządkowane w poszczególnych relacjach między krajami członkowskimi - pokazały, że tożsamość UE jest wewnętrznie sprzeczna. Nie może być tylko twórcza, skoro ma w sobie pierwiastek destrukcji. Nie może być logiczna, skoro uznano, że taka się nie opłaca, lepiej, żeby była genitalna, czyli dająca upust popędom, emocjom, doraźnym potrzebom wg norm pozwalających na względną akceptację tego, co tanatyczne. Myślenie tanatyczne to myślenie niespójne, schizoidalne i niemetodyczne, niekonsekwentne, to myślenie zdefraudowane przez doraźne cele i działania. To dlatego partia rządząca w Polsce (wraz z koalicjantami) powtarza, iż sprawy praworządności to sprawy wewnętrzne każdego kraju, ale już wstrzymywanie dopłat z funduszy unijnych spowodowane krytyczną oceną praworządności w Polsce przez podmioty do tego upoważnione, nazywa kakofoniąa ${ }^{8}$ Nie idealizuję wspólnoty logicznej, lecz pragnę pokazać, iż zadaniem krajów członkowskich UE jest wypracowanie balansu między tym, co merytoryczne i niemerytoryczne, ,najlepszym” mediatorem w tej opozycji jest właśnie myślenie potoczne.

\section{Liberalizm ewolucyjny}

W 1947 roku ogłoszono tzw. manifest oxfordzki podpisany przez sygnatariuszy z 19 krajów9. Jego autorzy już na wstępie zaznaczyli, że w Europie, która doświadczyła dwóch wojen światowych, wciąż odczuwane są ich konsekwencje w postaci nieładu, strachu, biedy i głodu. W dużej mierze to odejście od wartości liberalnych, zdaniem autorów manifestu, przyczyniło się do zaistniałej sytuacji.

Liberalizm ewolucyjny rozumiem zatem jako poszanowanie wolności do życia w sensie biologicznym jako sensie podstawowym odnoszącym się do złożoności ludzkiej natury, która nie jest imponderabilna, lecz rzeczywista, złożona i nieprzewidywalna. Zamiast więc myśleć o liberalizmie mającym swe źródło w myśleniu religijnym, w kulturze sekularnej i postsekularnej, szczególnie zaś w filozofii, sugeruję przemy-

${ }^{8}$ https://oko.press/komisja-europejska-pieniadze-dla-polski-zablokowane-przez-prawny-polexit-w-tk/, 12.10.2021.

${ }^{9}$ https://liberal-international.org/who-we-are/our-mission/landmark-documents/politicalmanifestos/oxford-manifesto-1947/, 12.10.2021. 
ślenie liberalizmu w kontekście ewolucji i bioróżnorodności jako fundamencie każdej wspólnoty.

Przykładowo w Polsce 74 lata później, licząc od roku, w którym podpisano manifest, populiści o prawicowym rodowodzie traktują liberalizm jako źródło zła, a ich wyborca zazwyczaj nie odróżnia liberalizmu od libertynizmu. Nad pytania o wolność sytuowane są działania, które umożliwiają zaspokajanie konsumenckich potrzeb. I nic w tym zdrożnego. Tak jest, gdyż projekt Oświecenia rozpadł się w moim przekonaniu nie z powodu złego rozumienia fundamentalnych idei, mówiąc językiem współczesnym, emancypacyjnych, spośród których wydobycie jednostki ze zbiorowości czy oddzielenie życia religijnego od życia świeckiego okazują się najoczywistsze i najbardziej konieczne, lecz dlatego, że człowiek dążący do wolności, opisujący siebie w horyzoncie semantycznym, jakże złożonym, jakże historycznie i kulturowo uwarunkowanym, tego pojęcia - nie przestał być wciąż zwierzęciem w sensie biologicznym. Od razu zaznaczę: nie zamierzam stygmatyzować zwierzęcości w człowieku, bo oznaczałoby to, że to, co ludzkie - nie jest naturalne, a także, że za degrengoladę projektów, w której wpisany jest rozwój ku tzw. lepszej przyszłości, odpowiada stereotypowo pojmowana „dzika”, ,nieprzewidywalna” natura w człowieku. Dzięki badaniom w obszarze humanistyki ekologicznej (Domańska, 2013, s. 13-32), dzięki refleksji ekokrytycznej (Barcz, 2016; Howarth, 1996, s. 69-92) można z całą pewnością stwierdzić, że jeśli nawet nie tyle więcej wiemy jako ludzie o sobie, to przynajmniej znów odkrywamy nas samych jako część natury - nie będąc żadnym jej centrum, żadną jej koroną, ot zwierzęciem, które wytwarza sferę symboliczną, aby opisać to, co się w niej mieści i przeczuwać to, że wiele rzeczy jeszcze należy poznać. Jesteśmy jednak jedynym gatunkiem zwierzęcym, którego działania zagrażają wszystkim pozostałym (Hoffman, 2021). Na marginesie dodam, że ta świadomość dociera nawet do takich „tradycjonalistów" jak Alasdair Macintyre, którego najnowsza wydana w języku polskim książka Zależne zwierzęta rozumne, choć nie jest rewolucyjna, to jedna szkicuje horyzont odpowiedzi na jedno z ważniejszych współcześnie pytań: „dlaczego ważne jest dla nas pochylenie się nad podobieństwami i zrozumienie podobieństw między istotami ludzkimi i innymi gatunkami inteligentnych zwierząt?" (Macintyre, 2021, s. 8) ${ }^{10}$. Refleksja ekologicznie modelująca współczesne dyskursy wynika z coraz większej świadomości na temat nieodwracalnych skutków degradacji środowiska naturalnego, a także z coraz większej naszej wiedzy, stopniowo uwalnianej z religijnych ram, o życiu w sensie biologicznym w całej jego złożoności.

Funkcjonując zaś w świecie, w którym zarządzanie strachem i kryzysami staje się najbardziej opłacalną politycznie walutą, obywatele godzą się na stopniowe, nienachalne ograniczanie własnych swobód obywatelskich, dostarczając rządzącym ogromu informacji na swój temat. Obecność kamer w przestrzeniach publicznych, rozpowszechnianie informacji o sobie w social media, zgoda na coraz większe podatki przeznaczone na sektor obronności to tylko najoczywistsze przykłady bankructwa społeczeństw Europy jako członków wspólnoty ufundowanej na wartościach liberalnych - chodzi o systematyczne ograniczanie własnej wolności za cenę minimalizacji

${ }^{10}$ Namysł filozofa jest źródłem licznych wątpliwości i daje asumpt do tego, by krytycznie się odnieść do wielu jego ustaleń opartych na schematycznym myśleniu, jednak warto docenić wywód i samą potrzebę jego artykulacji. 
zagrożeń (realnych i wykreowanych przez rządzących). Oczywiście, większość powyższych charakterystyk to reakcje Europy na działania niełatwych partnerów typu Rosja czy Turcja. Reakcje, ano właśnie. Ogólny wymiar powyższej konstatacji można zobrazować przykładowo następującą zależnością: Facebook czy Twitter ogólnie wpłynęły na banalizację dyskursów politycznych, przekształcając pomówienia, plotki czy komentarze w fakty społeczne, o których każdy może rozmawiać, do których każdy może się odnosić, na podstawie których podejmowane są decyzje wyborcze. Myślenie potoczne jest dominującą ramą poznawczą w tego typu mediach. Oto ,ja” dotychczas osamotniony w wyrażaniu własnych opinii - znajduję naśladowców w sieci. Im większa okazuje się ich liczba, tym lepiej - wszak utrwalają oni i rozpowszechniają niemal każdą głoszoną przeze mnie opinię. W filozoficznych koncepcjach prawdy mówiono m.in. o definicji klasycznej, utylitarnej, koherencyjnej, na skutek oddziaływania mediów społecznościowych dodałbym kolejną jej definicję: prawda jest funkcją społecznego oddziaływania głoszonej przeze mnie opinii na odpowiednią liczbę odbiorców. Im jest ich więcej, im więcej zyskuje się polubień i udostępnień, tym dana wypowiedź staje się bardziej prawdo-podobna ${ }^{11}$. To właśnie social media pokazały, jak wielu z nas to specjaliści od Europy w stanie uśpienia, których aktywuje określony temat, wątek, autorka i autor jakiegoś komentarza, profilu. Osobliwego znaczenia nabiera $\mathrm{w}$ tym kontekście jedna $\mathrm{z}$ definicji myśli potocznej zaproponowana przez Clifforda Geertza: „Myśl potoczna nie jest tym, co wolny od frazesów umysł spontanicznie wychwytuje, ale tym, do czego umysł pełen z góry przyjętych założeń dochodzi" (Geertz, 2005, s. 91). Myśl potoczna jest ogółem przekonań, którymi dysponujemy, a których potwierdzenia poszukujemy w otaczającym nas świecie. Wiemy to, co wiemy, a to gwarantuje nam komfort poznawczy, dlatego myślenie krytyczne, poznawanie różnych punktów widzenia jest dla nas w tym kontekście niebezpieczne, bo wyrywa nas ze strefy „poznawczego” komfortu (lub nawet może ją zniszczyć).

Myśl potoczna w moim przekonaniu, choć wyraża się ją w języku codzienności, jest na poziomie komunikacji międzyludzkiej tym, czym schematyczne, wyuczone zachowania zwierząt poruszających się w przestrzeni, w której nie muszą konfrontować się z zagrożeniem. Właśnie tak. Nie muszą. Taka przestrzeń jest tylko pozornie bezpieczna, każdy akt potraktowany przez nas jako akt podważający zasadność naszego trwania w sferze bezpieczeństwa - traktujemy jako atak, jako agresję, stąd nasze emocje w przestrzeni medialnej (to ciekawe, jak się przyzwyczailiśmy do zjawisku hejtu) i społecznej (atak na osoby w maseczkach anty-covidowych w przestrzeniach galerii handlowych, w środkach komunikacji miejskiej, atak na osoby uczestniczące w strajku kobiet itp.). Fakty, które gromadzimy jako fundamenty podtrzymujące naszą strefę bezpieczeństwa poznawczego, traktujemy jako oczywiste, wszak wiedza, którą posiadamy, to wiedza o Europie takiej, jaka jest, to oczywiste, naturalne i dziwi nas, a nawet wywołuje w nas agresję, że inni nie chcą przyjąć wyznawanych przez nas prawd. Przecież oczywiste jest, że Berlin „zawsze” chce „źle” dla Warszawy, nawet jeśli to „zawsze” liczymy od 2015 roku. Kto tego nie rozumie, to albo jest zdrajcą, albo jest ograniczonym intelektualnie zdrajcą. Nasza wiedza zmusza nas do działań, jesteśmy więc aktywni, nadając światu etykiety, znaczenia, wprowadzając podziały pokazujemy przecież, kto ma rację i kto nie

${ }^{11}$ Piszę prawdo-podobna, aby podkreślić dynamikę ruchu opinii od niepotwierdzonych, poprzez akceptowane do rozpowszechnionych, w domyśle traktowanych jako synonim prawdy. 
zasługuje na nasz szacunek. Wiedza potoczna jest praktyczna w sensie komunikacyjnym i społecznym. Sfera semiotyczna pokazuje, jak wiele jest podziałów w społeczeństwie polskim, przecież polscy „,prawdziwi patrioci” noszą opaski powstańcze na „patriotycznych" bluzach i dystansując się w ten sposób od tych, co nie noszą odzieży patriotycznej, chronią granic fantazmatycznych, będąc rycerzami narodu, Boga, są ludźmi honoru „broniącymi” kościołów przed hordą wszystkich „innych”. Wiedza potoczna jako wiedza powszechnie dostępna, praktyczna na poziomie komunikacji jest tym, czym na poziomie działań stadnych jest znaczenie terenu przez zwierzęta. Wiedza potoczna nie jest metodyczna i nie gromadzi się jej konsekwentnie, a funkcjonujące w niej prawdy mają postać łatwo przyswajalną, o czym pisałem trochę powyżej: „Polska dla Polaków i oczywiście heteroseksualna, i katolicka”, a „Unia Europejska stacza się w bezprawie” ${ }^{\prime 2}$, przecież to oczywiste. Dlatego wiedza jest praktyczna, bo służy nam do łatwego określenia wroga, a jednocześnie umożliwia nam wstąpienie w szeregi tych, co myślą tak jak my i dlatego mają rację (sic!). Wiedza nasza potoczna o Unii Europejskiej, o jej kondycji moralnej, jest następująca, tutaj parafrazuję myśl Clifforda Geertza, dostosowując ją do treści niniejszego eseju: Unia Europejska jest, jaka jest, a jest taka właśnie, bo inna być nie może. Decyzje podejmowane przez komisarzy są wymierzone w Polskę, bo tak jest. Jeśli masz co do tego wątpliwości, to zastanów się, po czyjej jesteś stronie. Unia jest taka właśnie i nie jest niczym mniej, niczym więcej. Trzeźwo o niej myśląc, realnie, to właściwie może jej nie być. Bez Unii było nam lepiej, a teraz znów musimy wstawać z kolan. Ile jeszcze, piękny narodzie? Wyrażenie metaforyczne nacechowane „wstawać $z$ kolan" uruchamia głęboką aksjologię. I to jest ciekawe. Myśl potoczna jest więc w tym sensie przezroczysta, wszak powyższe (przepraszam za ironiczny ton, ale proszę go traktować jako metonimię powszechnie krążących opinii) wypowiedzi muszą być łatwe w intelektualnej obsłudze, w której w miejsce pytań pojawiają gotowe, przywoływane eksplicytnie lub implicytnie oceny. Bo wiedza potoczna to akcelerator (doraźnych) ocen i karmiących się nimi emocji, wróg zwątpienia, czarna dziura krytycyzmu. Piszę o myśleniu potocznym przede wszystkim w kontekście Unii Europejskiej, pragnę wyraźnie jednak podkreślić, że jest to forma opisu doświadczeń dzielona przez wszystkie strony sporów politycznych, przez ludzi reprezentujących różny poziom wykształcenia, pochodzących z dużych i z małych miejscowości, bogatych i biednych.

Warto w tym miejscu przypomnieć rzecz oczywistą, a mianowicie, że wiele treści składających się na myślenia potoczne i na potoczną wiedzę to treści rozumiane dosłownie, przykładów w odniesieniu do Unii Europejskiej, podobnie jak w kontekście epidemii - można by podawać bez liku, wystarczy, że przywołam „klasyka” myśli epidemiologicznej: „Jedni lekarze powiedzą, że maseczki chronią przed wszystkim, a drudzy, co te maseczki faktycznie robią, co to znaczy wdychać z powrotem $\mathrm{CO}_{2}$, który wydychamy. Wdychamy tlen, wydychamy $\mathrm{CO}_{2}$ i powinniśmy wdychać z powrotem tlen, a nie ten sam $\mathrm{CO}_{2}$, czyli wdychać własne spaliny"13. Oddychanie spalinami jest na pewno niezdrowe i mało kto się w tym kontekście przejmie nienachalną wieloznacznością wynikającą z homonimii i potocznego rozumienia słowa „spaliny”, które zostaje w zacytowanej wypowiedzi ,stuningowane" semantycznie specjalistycznymi terminami typu:

${ }_{12}$ Por. https://dorzeczy.pl/opinie/214588/gorzka-diagnoza-kondycji-ue.html, 20.10.2021.

${ }^{13}$ Czytaj więcej na: https://www.wirtualnemedia.pl/artykul/edyta-gorniak-teorie-spiskowe-koro nawirus-maseczki-szczepienia-koniec-kariery-celebryty, 12.10.2021. 
„dwutlenek węgla”. Celebrytka ma większą siłę oddziaływania, niż specjalista w tym zakresie, gdyż mówi w sposób zrozumiały, jest znana, więc ma rację, a przy tym mówi niemal dokładnie to, co ja wiem na ten temat.

W wiedzy potocznej, która musi być powszechnie dostępna, nie potrzeba ekspertów, bo każdy, kto się wypowiada, ma się za specjalistę, dlatego social media to generatory myślenia potocznego jako dominującej formy opisu i wyjaśnienia największych tajemnic świata. Specjalistą prawdziwym, zgodnie z wyżej podaną definicją prawdy, staje się na przykład ten użytkownik, którego opinia zyskuje większą liczbę polubień, udostępnień w mediach społecznościowych. Oczywiście na taką sytuację ma też wpływ fakt, iż wielu specjalistów występujących w mediach tradycyjnych, dostosowując się do stylistyki i rytmu narzucanego przez konkretną stację telewizyjną podpisuje „cyrograf” z opinią publiczną, gdyż w krótkim czasie nieprzygotowanemu odbiorcy nie można wyjaśnić adekwatnie złożoności i zawiłości dotyczących Unii Europejskiej, nad którymi ślęczy się w bibliotekach i o których rozmawia się na niezliczonych konferencjach, dlatego dominuje poetyka skrótu, w którym rządzi metafora odwołująca się do powszechnej wiedzy, zdroworozsądkowych przekonań i „prawd” na miarę formuły programu, w którym się występuje.

Czy to ma oznaczać jedynie degrengoladę integracji i jedności ponad podziałami? Niekoniecznie. Najpierw należy opisać i wyjaśnić wpływ myślenia potocznego na zależności między podmiotami komunikacji korzystającymi z konkretnych mediów, aby kreować i transmitować określone treści. W tym kontekście potrzebne jest uwzględnienie wiedzy z zakresu biologii ewolucyjnej, etologii, kognitywistyki.

Pisałem powyżej o myśli potocznej krytycznie, wydobywając te elementy, które w moim przekonaniu składają się na bankructwo poznawcze i etyczne Unii Europejskiej, koncentrując się przy tym na polskiej perspektywie. Uniwersalność założeń odnoszących się do myśli potocznej - przy wszystkich różnicach historycznych, językowych, kulturowych, politycznych czy obyczajowych - można by stosować do innych państw członkowskich, i szerzej. Przykład pamięci o zielarkach z Gorzuchowa wśród lokalnej (i nie tylko) społeczności pokazuje jednak, że myśl potoczna jest również zasobem moralności, wiedzy i poznania, które mogą budować wspólnotę i trwałość tam, gdzie zawodzą instytucje i narzucane przez ich przedstawicieli regulacje. Innymi słowy, jeśli Unia Europejska ma trwać, to wiedza na jej temat musi być tak przekazywana, żeby w myśleniu potocznym każde jej „lustro” odzwierciedlało - przy różnorodności odbić - właśnie jedność (raczej rozumianą funkcjonalnie, mniej zaś esencjonalnie, to drugie byłoby możliwe i prawdopodobne, gdyby UE była wspólnotą wartości, gdyby w historii jej trwania powstały teksty i symbole, pojawiałyby się autorytety, które byłyby „,dobrami” wspólnymi, a tak przecież nie jest).

Żyjemy w świecie agresywnej i nie dającej się okiełznać zmiany. Złożoność cywilizacyjna jest tak ogromna, że trudno mówić o jakimś wspólnym celu narodu, a co dopiero Unii Europejskiej czy świata. Żeby powstrzymać globalne ocieplenie, musielibyśmy oddać środowisku naturalnemu powierzchnię wielkości Chin, aby na takim terenie odradzało się życie w całej swej bioróżnorodności. Na Ziemi żyje już ponad siedem i pół miliarda ludzi, 70\% z nas zamieszkuje miasta, Bliski Wschód jest tą częścią naszej planety, która przegrzewa się najszybciej i w krótkim czasie okaże się, że ludzie (choć myślę również o zwierzętach) nie dadzą rady tam żyć, a koszty przeży- 
cia będą większe, niż ryzyko wynikające z migracji (zresztą jesteśmy już świadkami migracji z tamtych rejonów). Gdy w tym kontekście uwzględnimy malejące zasoby wody pitnej, znikające lasy i całe gatunki zwierząt, gdy w tym kontekście uwzględnimy postępującą biedę i nędzę na świecie, to zrozumiemy, że pewnych procesów nie da się powstrzymać. Myśliciele Oświecenia - czy to Voltaire, czy Kant, choć każdy z nich na innym poziomie - zakładali jakiś rozwój, progres, zdolność człowieka do samodoskonalenia się pod pewnymi warunkami, mimo gorzkiej krytyki, która towarzyszyła tego typu refleksji. Myślę, lecz ta hipoteza wymagałaby gruntownych badań, że założenie o postępującej wiedzy człowieka, o jego rozwoju było niczym więcej, jak tylko świeckim palimpsestem religijnie umotywowanego celu (bez względu na różnice kontekstowe i ontologiczne). Otóż, my ludzie nie mamy jednego wspólnego celu. Nigdy nie mieliśmy. Często cel był eufemizmem, pod którym skrywano przemoc jednych wobec drugich, a taka jest przecież historia kolonizacji i każdej innej wojny o pokój. Nie inaczej jest dzisiaj. Złożoność świata przejawiająca się w różnorodności mechanizmów determinowanych ekonomicznie, politycznie czy religijnie powoduje, że możemy mówić o obszarach względnego uporządkowania relacji między ludźmi i między ludźmi oraz naturą. Zauważyłem, badając teksty kultury popularnej w różnych kontekstach, że autopojeza (rozumiana w niniejszym artykule jako samoporządkowanie się złożonych struktur, np. społecznych) możliwa jest po upadku, po katastrofie - i to jest niezwykły paradoks: samoorganizacja po katastrofie. Być może to jest właśnie konsekwencja bardzo późnej nowoczesności, w której żyjemy, właśnie ten paradoks. Autopojeza w złożonych systemach ekonomiczno-polityczno-militarno-społecznych nie jest możliwa na czas pojednania, tylko właśnie na czas rozpadu. Złożoność świata przeraża. Dlatego to, co na powierzchni daje się opisać np. w kontekście myśli potocznej modelującej relacje Polski z krajami członkowskimi UE, jest, jak sądzę, jestem nawet o tym przekonany, signifiant antropologicznego lęku przed rozpadem, którego już doświadczamy, a którego tylko skromną zapowiedzią jest to, co nazywam bankructwem Unii Europejskiej, za które odpowiada między innymi Polska. Przejawem tego bankructwa jest rozlewający się w łonie Wspólnoty populizm, nieudolność w tworzeniu wspólnej polityki wobec takich państw jak Chiny czy Rosja. Kurczymy się determinowani popędem śmierci do mniejszych struktur, aby zmierzyć się z tym, co nieuniknione w sytuacji, którą tylko pozornie będzie można lepiej kontrolować z takiej perspektywy. A szkoda, bo wspólnota oparta na wiedzy - w tym korzystającej z osiągnięć biologii ewolucyjnej - mogłaby być przydatna i niezbanalizowana. Piszę o tym, gdyż wychodzę z założenia, że ambiwalencja wpisana w myślenie potoczne umożliwia odsłonięcie kilku istotnych dla nas założeń: po pierwsze, potoczność nie wyklucza zgody, po drugie, nie implikuje zniszczenia i rozpadu, po trzecie, jest otwarta na różnorodność, o ile zrozumiemy, że źródła potoczności są nie w tym, że mało kto czyta dziś Adorno i Horkheimera, lecz w biologii, w ewolucji człowieka jako zwierzęcia - zwierzę w sytuacji zagrożenia ucieka, jeśli może albo w ostateczności walczy. Świadomość, że granice myślenia potocznego są dziś granicami Unii Europejskiej przynajmniej w sferze działań komunikacyjnych i w sferze symbolicznej, inspiruje do pytania o możliwości translacji tego, co trudne i ważne, często nazbyt krytyczne, choć osadzone w faktach (nigdy nie traktowałem kategorii postprawdy inaczej, jak tylko jako metafory) i konieczne - na język, który 
umożliwi wzięcie w nawias łatwopalnych emocji, choć i te są wyjaśnialne z perspektywy biologii ewolucyjnej.

\section{Zakończenie}

Przed jednoczącą się Europą wiele wyzwań. Warto myśleć o Unii Europejskiej jako o czasowniku, a nie rzeczowniku, jako o przejściu od tego, co możliwe do tego, co konieczne. Myślenie o UE jako czasowniku to uwrażliwienie nas na to, jak ważny jest język przeżywanej, doświadczanej, budowanej i demontowanej wspólnoty. Rozwój Unii Europejskiej jest nieodgadniony, heterogeniczny i polimorficzny. Nieoznaczony. Trzeba cierpliwości, sukcesem Europy jest jej wytrzymałość, mniej zaś osiąganie doraźnych celów. Gdy bowiem to drugie się nie udaje, to przewartościowuje się porażkę, każdą porażkę. Niniejszy artykuł jest szkicem problemów, w które uwikłana jest Unia Europejska na skutek oddziaływania myślenia potocznego traktowanego przeze mnie jako główna ramy poznawcza, opisowa oraz eksplanacyjna. Ogromnym w sferze epistemicznej oraz aksjologicznej wyzwaniem jest zbudowanie „translatora”, za pomocą którego tłumaczy się to, co krytyczne i merytoryczne na to, co potoczne, a tego, co potoczne na to, co biologiczne. Bez instytucji tłumaczy Europa będzie wciąż poligonem, na którym co rusz populiści będą się starali po raz wtóry, i trzeci, i czwarty tworzyć coś „na obraz i podobieństwo manekina”.

Byłoby lepiej dla życia na ziemi, dla emigrantów, którzy coraz częściej będą pukali do granic Europy, dla ludzi chcących tworzyć wspólnotę wielojęzyczną, poli-racjonalną oraz emocjonalną (myślenie krytyczne, myślenie potoczne, myślenie naukowe mogą być do pewnego stopnia względem siebie komplementarne), żeby człowiek kierowany popędami nie przyspieszał, biegnąc w kierunku przepaści.

Nie ma co wymagać za wiele od Unii Europejskiej, skoro nie oczekujemy za wiele od siebie i niewiele od siebie dajemy. Mylimy bowiem brak wysiłku z odpoczynkiem. Brak wysiłku to zniewolenie będące współczesną odmianą nowożytnego fatalizmu, który na poziomie naszych zachowań zwierzęcych wyjaśniać będzie strach przekształcany w agresję.

Myśl potoczna utrwala z jednej strony fragmentaryczność w postrzeganiu świata, więc można odnieść wrażenie, że sytuacja ekologiczna, ekonomiczna i sytuacja polityczna, to zupełnie inne pokoje pałacu, w którym zamieszkuje wspólnota, a z drugiej strony wprowadzanie takiego myślenia powoduje złudne przekonanie, że analogie (to, co się dzieje, już kiedyś było) i hiperbole (czeka nas katastrofa i nic się nie da z tym zrobić) - tak właściwe dla myślenia potocznego, podobnie jak fałszywe implikacje oparte na schemacie: jeśli p, to q (jeśli mamy wodę w kranie, to nie ma problemów ekologicznych), umożliwiają uchwycenie złożoności świata i zapanowanie nad tym, co się dzieje. Takie powierzchowne wykorzystanie wiedzy nie przekształca naszych postaw i nie redefiniuje priorytetów, nie zmusza do działania wg nowych wzorców. I to jest największy problem myślenia potocznego, że ono nie transformuje, lecz utrwala (poprzez powielanie tych samych wzorców, treści, schematów myślenia) zastaną sytuację i nasze wobec niej nastawienie. Ogromnym wyzwaniem okazuje się zatem to, co wydaje się pozornie banalne, czyli translacja. Żeby zmienić nastawienie 
Polaków - tej w każdym razie części społeczeństwa, która jest niechętna UE, trzeba zrozumieć, z czego wynika myślenie potoczne oraz stopniowo pokazywać, że to, co dziś jest kwestią wyboru, jutro okaże się końcem świata, który znamy - i dotyczy to Polski w UE, i Europy w kontekście środowiskowych problemów, problemów globalnych. Niebezpieczeństwo emocji, które kierują naszymi decyzjami, wynika z tego, że mogą być różni reżyserzy iluzji, którym będziemy ulegać i jedno jest pewne, gdy się rozpadniemy jako wspólnota, nie spotkamy się przy tym samym wodopoju. Właśnie dlatego przekonani, że jesteśmy świadkami pełzającej apokalipsy, chcemy się zbroić (ten schemat mamy sprawdzony) i czekać na wrogów, a gdy się spóźniają, to sobie ich wymyślamy (kolejny znany schemat). Relacje między krajami członkowskimi Unii Europejskiej i Polską są relacjami politycznymi, prawnymi, kulturowymi i ekonomicznymi, ale także, co równie ważne - ekologicznymi. Myślenie potoczne opiera się na niebezpiecznej zamianie muzeum i laboratorium. Do muzeum się wchodzi i zwiedza jego ekspozycje, w laboratorium się pracuje.

Użyłem metafory pałacu, aby wydobyć niebezpieczeństwo złudzenia, w którym żyjemy, a które wynika $\mathrm{z}$ różnych naszych ograniczeń. $\mathrm{W}$ tym pałacu zaczyna brakować świeżej wody, do jego drzwi pukają coraz większe grupy ludzi prawdziwie głodnych, a poza tym w pałacu straszy (to wiedzą specjaliści od PR-u partii rządzącej w Polsce, którzy wciąż ,żonglują” startymi, zużytymi, ale hałaśliwymi i niebezpiecznymi demonami uprzedzeń i uproszczeń) (Kaźmierczak, 2009, s. 213-230). Nie ma jednak pałacu (Leder, 2014) ${ }^{14}$. I nigdy nie było. Są namioty.

\section{Bibliografia}

Barcz A. (2016), Realizm ekologiczny. Od ekokrytyki do zookrytyki w literaturze polskiej, Katowice. Bielik-Robson A. (2012), Erros. Mesjański witalizm i filozofia, Kraków.

Bringsvaerd T. A. (2020), Hau. Psy, pieski i bestie w baśniach, mitach i wierzeniach, thum. M. Skoczko, Warszawa.

Domańska E. (2013), Humanistyka ekologiczna, „Teksty Drugie”, nr 1-2.

Geertz C. (2005), Wiedza lokalna. Dalsze eseje z zakresu antropologii interpretatywnej, thum. D. Wolska, Kraków.

Hartley J. (1996), Popular Reality. Journalism. Modernity. Popular Culture, Hodder Arnold.

Hoffman K. (2021), Antropocen, kapitałocen oraz ich (i nasze) przyszłości, https://czaskultury.pl/ artykul/antropocen-kapitalocen-oraz-ich-i-nasze-przyszlosci/?fbclid=IwAR3QoG0xi0Tfxiq 2mazoIBAudxxpDJGKOcFYCXSEgOVRzKw-BNi0vP8YMzs, 28.10.2021.

Hołówka T. (1986), Myślenie potoczne, Warszawa.

Howarth W. (1996), Some Principles of Ecocriticism, w: The Ecocriticism Reader. Landmarks in Literary Ecology, ed. by Ch. Glotfelty, H. Fromm, University of Georgia Press.

Jameson F. (2021), Postmodernism and Consumer Society, https://art.ucsc.edu/sites/default/files/ Jameson_Postmodernism_and_Consumer_Society.pdf, 12.09.2021.

Karner Ch. (2020), Constructions and (attempted) deconstructions of 'memory nationalism': Central European lessons, "Journal of Contemporary European Studies", https://doi.org/10.1080/14 782804.2020 .1862072$.

${ }^{14}$ Doskonałym wprowadzeniem, nie tylko na poziomie metafory poznawczej w kontekście Polski, które można potraktować jako analizę zachowań wyniesionych z pałacu, którego nie było, jest wciąż bardzo aktualna i ważna książka Andrzeja Ledera zatytułowana Prześniona rewolucja. 
Kaźmierczak M. (2009), Funkcje metafor w relacjach Polski z Unią Europejska, „Przegląd Zachodni" nr 3, s. 213-230.

Kloch Z. (2006), Odmiany dyskursu, Semiotyka życia publicznego w Polsce po 1989 roku, Wrocław. Korab-Karpowicz W. J. (2010), Historia filozofii politycznej. Od Tukidydesa do Locke'a, Kęty.

Leder A. (2014), Prześniona rewolucja. Ćwiczenie z logiki historycznej, Warszawa.

Leggewie C., Welzer H. (2012), Koniec świata, jaki znaliśmy. Klimat, przyszłość i szanse demokracji, thum. P. Buras, Warszawa.

Macintyre A. (2021), Zależne zwierzęta rozumne. Dlaczego ludzie potrzebuja cnót, thum. W. Szymański, Łódź.

Schulz B., Traktat o manekinach albo wtórna księga rodzaju, https://wolnelektury.pl/katalog/lektura/ sklepy-cynamonowe-traktat-o-manekinach-albo-wtora-ksiega-rodzaju.html, 15.10.2021.

Sulima R. (2000), Antropologia codzienności, Kraków.

Tenenbom T. (2016), I Sleep in Hitler's Room: An American Jew Visits Germany, Gefen Books.

\section{Źródla internetowe:}

https://oko.press/komisja-europejska-pieniadze-dla-polski-zablokowane-przez-prawny-polexit-w$\mathrm{tk} /, 12.10 .2021$.

https://iberal-international.org/who-we-are/our-mission/landmark-documents/political-manifestos/ oxford-manifesto-1947/, 12.10.2021.

https://dorzeczy.pl/opinie/214588/gorzka-diagnoza-kondycji-ue.html, 20.10.2021.

https://www.wirtualnemedia.pl/artykul/edyta-gorniak-teorie-spiskowe-koronawirus-maseczki-szcze pienia-koniec-kariery-celebryty", 12.10.2021.

\section{Streszczenie}

Główna hipoteza artykułu pt. 'Specjaliści' od UE. O myśleniu potocznym jako granicy poznania wspólnoty europejskiej a sprawa polska brzmi: rozumienie Unii Europejskiej jest kształtowane i wyznaczane przez zdrowy rozsądek (myślenie potoczne). Autor artykułu pokazuje, że kruchość UE jest zakorzeniona w doświadczeniu pornografii demokracji, w której zasady i prawa fundamentalne dla społeczeństwa demokratycznego są wykorzystywane przeciwko obywatelom (por. perspektywa polska czy węgierska). Dlatego zdrowy rozsądek jest traktowany jako granica myśli politycznej. Każdego można w tym kontekście potraktować jako specjalistę od ekonomii, ekologii, spraw międzynarodowych, historii itp. Zdrowy rozsądek urealnia emocje a nie fakty, dlatego można zaobserwować wiele przykładów dyskursów wykluczenia. Jest też inny ważny kontekst: status liberalizmu. Autor artykułu jest przekonany, że myśląc o liberalizmie powinniśmy mieć na uwadze „,zwrot biologiczny”.

Słowa kluczowe: Unia Europejska, Polska, myśl potoczna, liberalizm, krytycyzm

\section{"Specialists" about European Union. Common sense as the limit of cognition of European community in the context of Polish policy}

\section{Summary}

The main hypothesis of the article titled "Specialists" about European Union. Common sense as the limit of cognition of European community in the context of Polish policy is: under- 
standing of European Union is shaped and determined by common sense (colloquial thinking). The author of the paper shows that the fragility of UE is rooted in the experience of the pornography of democracy where the rules and law fundamental for democratic society are used against citizens (compare with Polish or Hungarian perspective). That is why common sense is treated as the limit of political thought. Everybody in this context can be treated as the specialist of economy, ecology, international affairs, history, etc. Common sense makes emotions much more real than the facts that is why we can observe a lot of examples of the discourses of exclusion. There is also another important context: the status of liberalism. The author of the paper is convinced that in thinking about liberalism we should concern "biological turn".

Key words: European Union, Poland, common sense, liberalism, critical thinking 